\title{
MENINGKATKAN HASIL BELAJAR KOGNITIF DENGAN MENGGUNAKAN MODEL PEMBELAJARAN DIRECT INSTRUCTION DIPADUKAN METODE FISH BOWL PADA SISWA KELAS V SDN TELUK TIRAM 2 BANJARMASIN
}

\section{Rahidatul Laila Agustina, Rifda Mardian Arif, dan Yudha Adrian}

\author{
Program Studi PGSD \\ STKIP PGRI Banjarmasin
}

Jalan Sultan Adam, Komplek H. Iyus, No. 18 RT.23 Banjarmasin,

Kalimantan Selatan. Kode pos 70121

email: rahidatul.agustina@gmail.com

\section{ABSTRAK}

Penelitian ini bertujuan untuk mengetahui penggunaan model pembelajaran direct instruction dipadukan metode fish bowl dalam meningkatkan hasil belajar kognitif siswa kelas V sdn teluk tiram 2.

Metode yang digunakan dalam penelitian ini adalah penelitian tindakan kelas yang dilaksanakan dalam dua siklus penelitian, setiap siklus terdiri dari 2 kali pertemuan. Subyek penelitian ini adalah siswa kelas V SDN Teluk Tiram 2 pada semester ganjil tahun ajaran 2017/2018, dengan jumlah siswa 24 orang. Pengumpulan data dalam penelitian ini diperoleh melalui teknik observasi dan tes tertulis, sedangkan teknik analisis data yang digunakan adalah ratarata dan persentase.

Hasil penelitian ini diperoleh bahwa Penerapan model pembelajaran Direct Instruction dipadukan dengan metode Fish Bowl dapat meningkatkan hasil belajar siswa pada pelajaran IPS. Peningkatan ini dapat dilihat dari hasil belajar siswa yang selalu mengalami peningkatan di setiap pertemuannya, Hasil belajar siswa nilai rata-rata 52,5 jadi 60,2 di siklusI dan disiklus II 70,2 menjadi 82,9. Dilihat dari rata-rata nilai tiap pertemuan ada peningkatan yang sangat signifikan, dan telah mencapai tingkat ketuntasan secara klasikal karena dilihat dari presentase ketuntasan sudah berada diatas standar ketuntasan minimal.

Kata Kunci: hasil belajar kognitif, direct instruction, fish bowl

\section{PENDAHULUAN}

Pelaksanaan pendidikan di setiap satuan pendidikan telah diatur oleh pemerintah pusat. Peraturan pelaksanaan pendidikan formal khususnya di tingkat sekolah dasar (SD) diatur melalui pemberlakuan kurikulum. Kurikulum merupakan suatu rancangan pelaksanaan pendidikan secara makro dan mikro. Kurikulum secara makro yaitu kurikulum yang diterbitkan oleh pemerintah pusat. Selanjutnya, kurikulum tersebut diimplementasikan di setiap satuan pendidikan. Kurikulum tersebut adalah kurikulum tingkat satuan pendidikan (KTSP).

Pada kurikulum KTSP di tingkat sekolah dasar (SD) terdiri atas beberapa mata pelajaran yang wajib dibelajarkan kepada siswa dalam rangka melaksanakan pendidikan formal. Salah satu mata pelajaran yang dibelajarkan di tingkat sekolah dasar adalah Ilmu Pengetahuan Sosial (Berdasarkan 
hasil penelitian dapat diketahui bahwa ada peningkatan hasil belajar siswa. Hasil pembelajaran pada tahap siklus II lebih baik jika dibandingkan dengan pembelajaran pada tahap prasiklus dan siklus I. Hal ini dapat dilihat dari meningkatnya nilai rata-rata siswa. Selain itu kemandirian siswa mulai tampak dan perhatian dalam pembelajaran lebih meningkat daripada pada tahap prasiklus dan siklus I. Hal ini sesuai dengan teori dari Sudjana (2013:45) mengemukakan bahwa setiap proses belajar mengajar keberhasilannya diukur dari seberapa jauh hasil belajar yang dicapai siswa, disamping diukur dari segi prosesnya. Hasil belajar merupakan perubahan perilaku secara keseluruhan bukan hanya salah satu aspek potensi kemanusiaan saja (Suprjono, 2009:7). Menurut Purwanto (2013:46) Hasil belajar pada hakikatnya adalah perubahan perilaku akibat belajar. Perubahan perilaku disebabkan karena dia mencapai penguasaan atas sejumlah bahan yang diberikan dalam proses belajar mengajar. Pencapaian itu didasarkan atas tujuan pengejaran yang telah ditetapkan.). Pembelajaran Ilmu Pengetahuan Sosial (IPS) merupakan ilmu atau pelajaran yang berhubungan dengan pengetahuan sosial dan keterampilan dasar yang berguna bagi peserta didik dalam kehidupan sehari-hari.Pembelajaran IPS merupakan dasar-dasar pengetahuan konsep tentang pengetahuan sosial yang beranjak dari lingkungan dimana siswa itu berada hingga pada konsep lebih luas lagi yaitu Bangsa dan Negara (Djahri, 2006:5).

Menurut Trianto (2012:176) “tujuan utama Ilmu Pengetahuan Sosial (IPS) ialah untuk mengembangkan potensi peserta didik agar peka terhadap masalah sosial yang terjadi di masyarakat, memiliki sikap mental positif terhadap perbaikan segala ketimpangan yang terjadi, dan terampil mengatasi setiap masalah yang terjadi sehari-hari baik yang menimpa dirinya sendiri maupun yang menimpa kehidupan masyarakat".

Menurut kurikulum 2006 (Depdiknas, 2011:122) Mata pelajaran IPS bertujuan agar peserta didik memiliki kemampuan sebagai berikut : a) Mengenal konsep-konsep yang berkaitan dengan kehidupan masyarakat dan lingkungannya, b) Memiliki kemampuan dasar untuk berfikir logis dan kritis, rasa ingin tahu, inkuiri, memecahkan masalah, dan keterampilan dalam kehidupan sosial, c) Memiliki komitmen dan kesadaran terhadap nilai-nilai sosial dan kemanusiaan, d) Memiliki kemampuan berkomunikasi, bekerjasama dan berkompetisi dalam masyarakat yang majemuk, di tingkat lokal, nasional, dan global.

Hal ini berarti mata pelajaran IPS mempersiapkan peserta didik agar mampu menghadapi tantangan-tantangan masa depan yang terjadi dalam lingkungan masyarakat sehingga dapat diterapkan dikehidupan sehari-hari. Oleh karena itu diharapkan peserta didik dapat menguasai materi IPS.Materi tersebut hendaknya dipersiapkan dan dirancang berkesinambungan dengan penekanan pada setiap tingkat yang berbeda.

Berdasarkan studi pendahuluan di SDN Teluk Tiram 2 Banjarmasin. Melalui observasi ditemukan beberapa permasalahan yang muncul saat proses pembelajaran berlangsung. Guru 
menyampaikan pelajaran dengan komunikasi satu arah. Artinya, guru hanya melakukan transfer ilmu pengetahuan kepada siswa, sedangkan siswa tidak memberikan respon kepada guru. Siswa tidak percaya diri dalam menyampaikan pertanyaan dan mengutarakan pendapat. Siswa tidak terlalu antusias mengikuti pelajaran. Siswa tidak terlalu memperhatikan ketika guru memberikan pelajaran di dalam kelas. Acapkali, guru menerapkan metode kerja kelompok, namun kerja kelompok sering didominasi oleh siswa yang popular. Siswa rajin yang lebih mendominasi dalam kerja kelompok,sedangkan siswa malas hanya menuggu hasilnya saja. Dengan demikian, kerja kelompok tidak maksimal dalam proses pembelajaran.

Berdasarkan dokumentasi yang dilaksanakan di SDN Teluk Tiram 2 Banjarmasin. Peneliti menemukan bahwa sebagian besar siswa yang menempuh mata pelajaran PPKN di kelas V belum memenuhi KKM yang tentukan oleh sekolah tersebut. 70\% dari keseluruhan siswa tidak memenuhi KKM di kelas V tersebut. Sedangkan 30\% sisa siswa memenuhi KKM pada mata pelajaran PPKN di sekolah tersebut. Dengan demikian, pelaksanaan pembelajaran di kelas V pada mata pelajaran PPKN belum sukses.

Untuk menyikapi hal tersebut, maka peneliti menawarkan beberapa metode pembelajaran yang variatif. Tujuannya untuk memberikan variasi pembelajaran di kelas V pada mata pelajaran IPS. Metode pembelajaran yang akan diterapkan pada mata pelajaran PPKN di SDN Teluk Tiram 2 Banjarmasin adalah metode pembelajaran Direct Instruction dan Fish Bowl. Direct Instruction atau metode Pengajaran langsung adalah metode pembelajaran yang berpusat pada guru. Metode ini mempunyai 5 langkah dalam pelaksanaannya, yaitu menyiapkan siswa menerima pelajaran, demontrasi, pelatihan terbimbing, umpan balik, dan pelatihan lanjut (mandiri) (Nur, 2000:7).

Metode pembelajaran Direct Instruction memposisikan guru sebagai sumber belajar. Guru memberikan penjelasan-penjelasan terkait materi yang dipelajari terkait dengan mata pelajaran IPS. Jika materi-materi yang belum jelas, maka guru memberikan demonstrasi kepada siswa agar mempermudah siswa menyimak materi yang dipelajari. Setelah, guru memberikan penjelasan kepada siswa, guru mengecek pemahaman siswa melalui pertanyaan-pertanyaan yang diajukan kepada siswa. Setelah guru mendapatkan umpan balik, maka guru dapat memberikan latihan kepada siswa.

Menurut (Sudjana, 2010:144-145) Teknik cawan ikan (fish bowl technique) adalah kegiatan pembelajaran dalam bentuk diskusi yang diamati. Metode Fishbowl adalah salah satu metode yang menerapkan pembelajaran kooperatif. Metode ini merupakan suatu metode kerja kelompok yang terdiri dari dua kelompok yaitu kelompok dalam dan kelompok luar. Kelompok dalam bertugas membahas tema atau tugas yang diberikan, sedangkan kelompok luar adalah memberikan pertanyaan dan sanggahan kepada kelompok dalam. Kelompok dalam lebih kecil dibandingkan dengan lingkaran kelompok luar. Kelompok dalam biasa disebut sebagai kelompok bicara. Semua 
orang yang duduk di kelompok dalam boleh berbicara suka-suka sesuai dengan pertanyaan diskusi. Pertanyaan diskusi diawali oleh fasilitator dan selanjutnya bisa berkembang sesuai dengan minat peserta. Biasa fasilitator hanya menyampaikan pertanyaan terbuka yang sederhana. Kelompok luar biasanya disebut kelompok pendengar. Mereka hanya boleh mendengar dengan aktif. Sama sekali dilarang bicara.

Tujuan peneliti memadukan metode pembelajaran Direct Instruction dan Fish Bowl agar memberikan variasi pembelajaran PPKN di dalam kelas. Guru memiliki peran ganda dalam proses pembelajaran di dalam kelas. Peran pertama adalah sebagai sumber belajar. Peran kedua sebagai fasilitator proses pembelajaran di dalam kelas. Peran sebagai sumber belajar berlaku saat guru menerapkan memberikan penjelasan-penjelasan kepada siswa. Setelah siswa dirasa paham, guru memberikan penguatan melalui metode pembelajaran Fish Bowl. Dengan demikian, proses pembelajaran di dalam kelas tidak lagi monoton sehingga memberikan motivasi siswa untuk aktif dalam mengikuti proses pembelajaran di dalam kelas.

Mekanisme penerapan metode pembelajaran Direct Instruction dan Fish Bowl pada pelajaran PPKN. Guru selaku sumber belajar menerapkan metode pengajaran langsung di dalam kelas. Guru memberikan penjelasan-penjelasan kepada siswa tentang materi yang dipelajari oleh siswa. Guru menyampaikan poin-poin penting sehingga siswa akan lebih mudah dalam menerima pelajaran tersebut. Dengan demikian, guru telah menerapkan metode pengajaran langsung guna mempersiapkan siswa mengikuti pelajaran.

Langkah selanjutnya adalah guru menerapkan metode Fish Bowl. Pada sesi ini guru mengarahkan siswa untuk membentuk kelompok-kelompok kecil berbentuk mangkuk ikan. Pada praktiknya, kelompok dalam memberikan jawaban dan kelompok luar memberikan pertanyaan. Disini terjadi proses komunikasi beberapa arah antara guru ke siswa, siswa ke siswa lainnya. Dengan demikian, terjadi proses perpindahan peran guru yang sebelumnya sebagai sumber belajar menjadi fasilitator.

Untuk mengetahui mengetahui peningkatan sikap sosial, hasil belajar kognitif dan retensi siswa kelas V maka dilaksanakan penelitian tindakan kelas (PTK) yang berjudul: "Meningkatkan Sikap Sosial, Hasil Belajar Kognitif, dan Retensi Menggunakan Metode Pembelajaran Direct Instruction dipadukan Fish Bowl untuk Siswa Kelas V SDN Teluk Tiram 2 Banjarmasin.

\section{METODE}

Pendekatan penelitian yang digunakan dalam penelitian ini adalah pendekatan kualitatif. Menurut jenisnya penelitian yang digunakan adalah penelitian tindakan (Action Research) berupa penelitian tindakan kelas (Classroom Action Research). Penelitian Tindakan Kelas (PTK) adalah penelitian yang dilakukan oleh guru di dalam kelasnya sendiri melalui refleksi diri, dengan tujuan 
untuk memperbaiki kinerjanya sebagai guru, sehingga hasil belajar siswa menjadi meningkat (Wardhani 2007:1.4). PTK ini dilakukan karena adanya masalah yang dihadapi pendidik dalam proses pembelajaran di kelas (Arikunto, 2006:106). Penelitian tindakan kelas merupakan suatu penelitian bersiklus yang dilakukan oleh guru, yang berdasar pada permasalahan rill yang ditemui dikelasnya, melalui langkah-langkah merancang, melaksanakan dan merefleksikan tindakan secara kolaboatif, partisipatif dan reflektif mandiri dengan tujuan untuk memperbaiki kualitas pembelajaran (Soekamto, dkk, 2009:6).Tujuan utama PTK adalah untuk memecahkan permasalahan nyata yang terjadi dikelas dan meningkatkan kegiatan nyata guru dalam pengembangan profesinya.

Lokasi penelitian adalah di Sekolahini beralamat di Jalan Antasan Raden Darat Kelurahan Teluk Tiram Kecamatan Banjarmasin Barat Kota Banjarmasin Provinsi Kalimantan Selatan Kode pos 70113. Subjek dalam penelitian Tindakan Kelas ini adalah siswa kelas Subjek dalam penelitian ini adalah seluruh siswa kelas V SDN Teluk Tiram 2 yangberjumlah 24 orangpada semester I (ganjil) tahun ajaran 2017/2018. Alasan pengambilan subjek penelitian ini karena peneliti merasa apa yang dicapai oleh sekolah tersebut masih belum optimal terutama dalam hal pembelajaran sehingga peneliti ingin meningkatkan kualitas pembelajaran dan hasil belajar siswa di SDN TelukTiram 2 agar mampu bersaing dalam hal kualitas dengan sekolah di perkotaan yang mempunyai sarana dan prasarana yang lengkap dan lebih memadai.

Model PTK yang dilakukan dalam penelitian ini adalah PTK kolaboratif. Model ini dipandang tepat karena masalah yang diangkat dalam penelitian ini adalah masalah yang terjadi di kelas $\mathrm{V}$ SDN Teluk Tiram 2. Dalam PTK ini peneliti sebagai pengamat partisipan dan kolaborasi dengan guru kelas V SDN Teluk Tiram 2. Dalam penelitian ini, peneliti bertindak sebagai instrumen kunci karena peneliti yang merancang, mengumpulkan data, menganalisis data, menarik kesimpulan, dan membuat laporan, sedangkan pelaksanaan pengajaran diserahkan pada guru kelas V SDN Teluk Tiram 2.

Sesuai dengan jenis penelitian yang dipilih yaitu penelitian tindakan kelas, maka penelitian ini menggunakan model penelitian tindakan dari (Arikunto, 2010:16) yaitu berbentuk spiral dari siklus yang satu ke siklus yang berikut. Setiap siklus memiliki planning (rencana), action (pelaksanaan), observasi (pengamatan) dan reflection (refleksi). Langkah pada siklus berikutnya adalah perencanaan sudah direvisi, pelaksanaan, pengamatan, dan refleksi. Sebelum masuk pada siklus 1 dilakukan tindakan pendahuluan yang berupa identifikasi permasalahan (observasi).

Data yang diperlukan dalam penelitian adalah datatentang hasil belajar siswa kelas V SDN Teluk Tiram 2. Instrumen yangdigunakan dalam penelitian ini adalah lembar observasiaktivitas guru dan siswa, dan tes hasil belajar. Analisis inidihitung dengan menggunakan deskriptif kualitatif dankuantitatif. 


\section{HASIL DAN PEMBAHASAN}

Berdasarkan hasil pengamatan yang dilakukan peneliti terhadap kegiatan siswa dalam proses pembelajaran baik siklus I maupun siklus II dapat diuraikan perbandingan hasil belajar siswa sebagai berikut:

Tabel 1 Perbandingan Hasil Belajar Siklus I dan siklus II

\begin{tabular}{|c|c|c|}
\hline Kegiatan & Nilai rata-rata & Ketuntasan Klasikal \\
\hline Siklus I & 60.2 & $57 \%$ \\
\hline Siklus II & 82.9 & $87 \%$ \\
\hline
\end{tabular}

Dilihat dari rata-rata nilai tiap pertemuan ada peningkatan yang sangat signifikan, dan telah mencapai tingkat ketuntasan secara klasikal karena dilihat dari presentase ketuntasan sudah berada diatas standar ketuntasan minimal. Adapun perbandingan persentase nilai hasil siswa dapat dilihat pada diagram berikut ini:

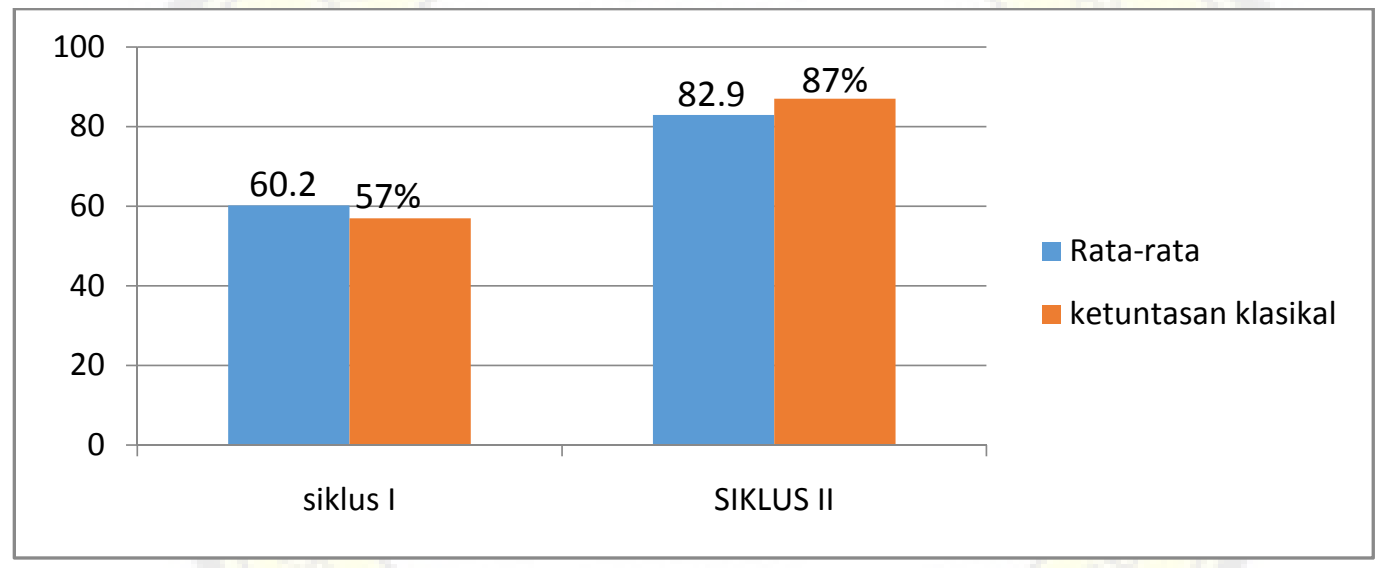

Diagram 1 Perbandingan Hasil Belajar Siklus I dan siklus II

Hasil belajar siswa pada siklus I pertemuan 1 rata-rata nilai 52.5 dengan tingkat ketuntasan persentase $33 \%$ siswa tuntas dan $67 \%$ siswa tidak tuntas, pada pertemuan 2 rata-rata nilai 60.2 dengan tingkat ketuntasan persentase siswa yang tuntas dan 57\%. Dilihat dari rata-rata nilai tiap pertemuan belum ada peningkatan yang cukup signifikan karena belum mencapai tingkat ketuntasan secara klasikal karena dilihat dari presentase ketuntasan masih dibawah tingkat ketuntasan. Oleh karena itu pembelajaran dilanjutkan ke siklus II. Pada siklus IIhasil belajar siswa pada pertemuan 1 rata-rata nilai 70.2 dengan persentase $70 \%$ siswa tuntas dan $30 \%$ siswa tidak tuntas, pada pertemuan 2 rata-rata nilai 82.9 dengan tingkat ketuntasan persentase $87 \%$ siswa yang tuntas dan 13\%. Dilihat dari rata-rata nilai tiap pertemuan ada peningkatan yang sangat signifikan, dan telah mencapai tingkat ketuntasan secara klasikal karena dilihat dari presentase ketuntasan sudah berada diatas standar ketuntasan minimal. 
Berdasarkan hasil penelitian dapat diketahui bahwa ada peningkatan hasil belajar siswa. Hasil pembelajaran pada tahap siklus II lebih baik jika dibandingkan dengan pembelajaran pada tahap prasiklus dan siklus I. Hal ini dapat dilihat dari meningkatnya nilai rata-rata siswa. Selain itu kemandirian siswa mulai tampak dan perhatian dalam pembelajaran lebih meningkat daripada pada tahap prasiklus dan siklus I. Hal ini sesuai dengan teori dari Sudjana (2013:45) mengemukakan bahwa setiap proses belajar mengajar keberhasilannya diukur dari seberapa jauh hasil belajar yang dicapai siswa, disamping diukur dari segi prosesnya. Hasil belajar merupakan perubahan perilaku secara keseluruhan bukan hanya salah satu aspek potensi kemanusiaan saja (Suprjono, 2009:7). Menurut Purwanto (2013:46) Hasil belajar pada hakikatnya adalah perubahan perilaku akibat belajar. Perubahan perilaku disebabkan karena dia mencapai penguasaan atas sejumlah bahan yang diberikan dalam proses belajar mengajar. Pencapaian itu didasarkan atas tujuan pengejaran yang telah ditetapkan.

Model pembelajaran Direct Instruction dipadukan dengan metode Fish Bowl memposisikan guru sebagai sumber belajar. Guru memberikan penjelasan-penjelasan terkait materi yang dipelajari terkait dengan mata pelajaran IPS. Jika materi-materi yang belum jelas, maka guru memberikan demonstrasi kepada siswa agar mempermudah siswa menyimak materi yang dipelajari. Setelah, guru memberikan penjelasan kepada siswa, guru mengecek pemahaman siswa melalui pertanyaanpertanyaan yang diajukan kepada siswa. Setelah guru mendapatkan umpan balik, maka guru dapat memberikan latihan kepada siswa.

Menurut (Sudjana, 2010:144-145) Teknik cawan ikan (fish bowl technique) adalah kegiatan pembelajaran dalam bentuk diskusi yang diamati. Metode Fishbowl adalah salah satu metode yang menerapkan pembelajaran kooperatif. Metode ini merupakan suatu metode kerja kelompok yang terdiri dari dua kelompok yaitu kelompok dalam dan kelompok luar. Kelompok dalam bertugas membahas tema atau tugas yang diberikan, sedangkan kelompok luar adalah memberikan pertanyaan dan sanggahan kepada kelompok dalam. Kelompok dalam lebih kecil dibandingkan dengan lingkaran kelompok luar. Kelompok dalam biasa disebut sebagai kelompok bicara. Semua orang yang duduk di kelompok dalam boleh berbicara suka-suka sesuai dengan pertanyaan diskusi. Pertanyaan diskusi diawali oleh fasilitator dan selanjutnya bisa berkembang sesuai dengan minat peserta. Biasa fasilitator hanya menyampaikan pertanyaan terbuka yang sederhana. Kelompok luar biasanya disebut kelompok pendengar. Mereka hanya boleh mendengar dengan aktif. Sama sekali dilarang bicara.

Tujuan peneliti memadukan metode pembelajaran Direct Instruction dan Fish Bowl agar memberikan variasi pembelajaran IPS di dalam kelas. Guru memiliki peran ganda dalam proses pembelajaran di dalam kelas. Peran pertama adalah sebagai sumber belajar. Peran kedua sebagai fasilitator proses pembelajaran di dalam kelas. Peran sebagai sumber belajar berlaku saat guru 
menerapkan memberikan penjelasan-penjelasan kepada siswa. Setelah siswa dirasa paham, guru memberikan penguatan melalui metode pembelajaran Fish Bowl. Dengan demikian, proses pembelajaran di dalam kelas tidak lagi monoton sehingga memberikan motivasi siswa untuk aktif dalam mengikuti proses pembelajaran di dalam kelas.

Pernyataan diatas juga dikemukakan oleh Roestiyah (1996:151) menjelaskan bahwa ada dua faktor penghambat proses belajar mengajar dapat berpengaruh pada proses belajar peserta didik. Adapun dua faktor tersebut adalah faktor internal dan eksternal. Lebih lanjut Roestiyah (1996:151) menjelaskan pengertian dua faktor internal dan eksternal adalah berikut ini:

1. Faktor internal, ialah faktor yang timbul dari dalam diri anak itu sendiri, sepertikesehatan, rasa aman, kemampuan, minat dan sebagainya.

2. Faktor eksternal, ialah faktor yang datang dari luar si anak, seperti kebersihan rumah, udara yang panas, lingkungan dan sebagainya.

Hasil penelitian ini didukung oleh Sudjana (2004:45) yang menyatakan bahwa hasil belajar adalah setiap proses belajar mengajar keberhasilannya diukur dari seberapa jauh hasil belajar yang dicapai siswa, disamping diukur dari segi prosesnya. Senada dengan itu Nasution (dalam Kunandar, 2008:276) berpendapat bahwa hasil belajar adalah suatu perubahan pada individu yang belajar, tidak hanya mengenai pengetahuan, tetapi juga membentuk kecakapan dan penghayatan dalam diri pribadi indvidu yang belajar.

\section{SIMPULAN}

Penerapan model pembelajaran Direct Instruction dipadukan dengan metode Fish Bowl dapat meningkatkan hasil belajar siswa pada pelajaran IPS. Peningkatan ini dapat dilihat dari hasil belajar siswa yang selalu mengalami peningkatan di setiap pertemuannya, Hasil belajar siswa nilai rata-rata 52,5 jadi 60,2 di siklusI dan disiklus II 70,2 menjadi 82,9. Dilihat dari rata-rata nilai tiap pertemuan ada peningkatan yang sangat signifikan, dan telah mencapai tingkat ketuntasan secara klasikal karena dilihat dari presentase ketuntasan sudah berada diatas standar ketuntasan minimal

\section{SARAN}

Berdasarkan hasil penelitian, pembahasan dan kesimpulan yang telah diuraikan dapat dikemukakan beberapa saran sebagai berikut:

\section{Bagi Peneliti}

Hendaknya peneliti dapat memanfaatkan hasil penelitian dengan sebaik-baiknya dan dapat menerapkan hasil temuan yang diperoleh untuk kepentingan dalam upaya peningkayan mutu pendidikan. 


\section{Bagi Guru}

a) Hendaknya guru IPS dapat menggunakan pendekatan dan model pembelajaran untuk meningkatkan hasil belajar siswa dalam pembelajaran IPS. Alternatif pendekatan dan model pembelajaran yang dapat digunakan untuk meningkatkan hasil belajar siswa yaitu model pembelajaran kooperatif tipe jigsaw. Karena selain meningkatkan hasil belajar siswa juga dapat meningkatkan aktivitas siswa dalam kegiatan pembelajaran. Namun hal tersebut juga harus didukung oleh aktivitas guru dalam menggunakan model pembelajaran.

b) Hendaknya dalam kegiatan pembelajaran sebaiknya merancang Rencana Pelaksanaan Pembelajaran (RPP) model pembelajaran kooperatif tipe jigsaw yang disesuaikan dengan konsep pelajaran yang akan disampaikan, pada mata pelajaran IPS sebaiknya dapat memperhitungkan segala keperluan yang akan disiapkan untuk menunjang jalannya pembelajaran agar menjadi lebih aktif, kreatif dan efektif.

\section{Bagi Siswa}

Pembelajaran yang dilakukan diharapkan dapat memberikan motivasi belajar yang lebih bervariasi agar siswa tidak mengalami kebosanan pada waktu kegiatan belajar mengajar. Selain itu diharapkan siswa lebih giat dan aktif selama pembelajaran di kelas, apabila ada pelajaran yang kurang difahami agar dapat bertanya kepada guru yang bersangkutan atau mendiskusikannya dengan teman yang sudah memahaminya. Untuk itu sangat diperlukan sekali interaksi dan kerjasama antar siswa agar pembelajaran menjadi sebuah proses yang menyenangkan.

4. Bagi Sekolah

Harapannya sekolah mampu memberikan pembelajaran yang mampu membuat siswa aktif dalam KBM agar terjadipeningkatan mutu pendidikan.

\section{DAFTAR RUJUKAN}

Aunurrahman, Belajar dan Pembelajaran, Bandung: Alfabeta, 2009

Arikunto, S. 2006. ProsedurPenelitian: SuatuPendekatan Praktik. Jakarta: RinekaCipta.

Buchari Alma, Guru Profesional Menguasai Metode dan Terampil Mengajar,

Bandung: Alfabeta, 2009

Darwan Syah, Strategi Belajar Mengajar, Jakarta: Diadit Media, 2009

Dazikiah Daradjat, Metodologi Pengajaran Agama Islam, Jakarta: Bumi Aksara, 2008

Gimin, Instrumen dan Pelaporan Hasil Dalam Penelitian Tindakan Kelas, Pekanbaru:UNRI Pers, 2008

Hartono, PAIKEM Pembelajaran Aktif, Inovatif, Kreatif, Efektif, dan Menyenangkan,Pekanbaru:

Zanafa, 2008 
Hisyam Zaini, Strategi Pembelajaran Aktif, Yogyakarta: Insan Madani CTSD, EdisiRevisi, 2008 Iskandar. 2012. PenelitianTindakanKelas. Jakarta: Referensi.

Muhammad Ali, Guru Dalam Proses Belajar Mengajar, Bandung: Sinar Baru Algensindo, 2008

Muhammad Uzer Usman, Upaya Optimalisasi KBM, Bandung: Remaja 1976

Muhibbin Syah, Psikologi Pendidikan dengan Pendekatan Baru, Bandung:PT.Rosdakarya, 2008

Mulyasa, Kurikulum Tingkat Satuan Pendidikan, Bandung: PT. Remaja Rosdakarya,2008

Nasution, Didaktik Asas-Asas Mengajar, Jakarta: Bumi Aksara, 2004

Riduwan. 2011. Skala Pengukuran Variabel-Variabel Penelitian. Bandung:Alfabeta.

Oemar Hamalik, Proses Belajar Mengajar. Bandung: Rosda. 2004

Silbermen, Active Learning 101 Cara Belajar Siswa Aktif, Bandung: Nusa Media, 2006

Arikunto, S. Penelitian Tindakan Kelas, Jakarta: Rineka Cipta, 2007 , Prosedur Penelitian Suatu Pendekatan Praktek, Jakarta: RinekaCipta. 1998

Djamarah, Syaiful Bahri. Strategi Belajar Mengajar, Jakarta: Rineka Cipta, 2006 Thursan Hakim, Belajar Secara Efektif, Jakarta: Puspa Swara, 2005

Wardani, I.G.A.K. \& Kuswaya W. 2008. Penelitian Tindakan Kelas. Jakarta: Universitas Terbuka. Sanjaya, Wina. Perencanaan dan Desain Sistem Pembelajaran, Bandung: Kencana,2008 Yatim Riayanto, Paradigma Pembelajaran, Jakarta: Kencana, 2009 